\title{
The Growth of a European Network of Labor Historians
}

\author{
Marcel van der Linden ${ }^{1}$ \\ International Institute of Social History
}

The first conference of the European Labour History Network (ELHN) took place on December 14-16, 2015, in Turin, Italy. It was, for the time being, the culmination of a development that has been going on for a number of years. Increasingly European labor historians work together across borders. Since the 1970s the number of research projects comparing two or more national cases has grown considerably, while in recent years transnational connections have attracted more attention as well. Likewise, labor historians now take Europe's imperial, colonial, and neocolonial past very seriously, and therefore the labor dimension of that past is explored more intensely (chattel slavery, indentured labor, convict labor, and so on).

Labor historians in Europe can rely on an extensive, but dispersed, infrastructure. The number of specialized archives and libraries is impressive. Already in 1882, exiles of the German Social Democratic Party created their own party archive in Switzerland. Their example was soon followed by partyunion alliances in Sweden (1902), Norway (1908), Denmark, and Finland (1909). Socially committed liberals and Christians began to collect documentation on the living and working conditions of the laboring classes as well as the "social question." This resulted in the founding of the Musée Social in Paris (1894) and of the Schweizerisches Sozialarchiv in Zürich (1906). Later on, more institutions followed, such as the International Institute of Social History in Amsterdam (IISH, 1935) and the Fondazione Giangiacomo Feltrinelli in Milan (1951).

Soon, journals and yearbooks originated as well. The first "real" labor history journal was the Archiv für die Geschichte des Sozialismus und der Arbeiterbewegung (1911-1930) of the Austro-Marxist Carl Grünberg, who would also, in 1924, become the first director of the famous Frankfurt Institute for Social Research. In 1936 IISH began to publish a yearbook, the International Review for Social History, and a Bulletin; after World War Two both periodicals were merged into a journal, the International Review of Social History (1956-present). The French historian Jean Maitron was instrumental in founding the Institut français d'histoire sociale (1948), which has played an important role through its journal Actualité de l'histoire-since 1960 (until the present) Le Mouvement Social. In 1958 the Feltrinelli Institute began to publish an authoritative annual review called Annali. In 1961 the Friedrich Ebert Foundation (which in the meantime had become the holder of German trade union archives and many other papers) launched a long 
series of thick yearbooks under the title Archiv für Sozialgeschichte. There upon regular publications followed in many other countries. Some of these perished again, but quite a few continue until the present day (see Table 1$){ }^{2}$

In parallel, labor historians since the late 1940s formed working groups and, somewhat later, associations. A study circle was founded in 1953 in milieux close to IISH in Amsterdam, with a bulletin that would later grow to become a leading Dutch-Flemish journal. ${ }^{3}$ A Social History Working Group (Arbeitskreis Sozialgeschichte) began in West Germany in 1957 with government support. The first real labor history association was the Verein für Geschichte der Arbeiterbewegung (Association for Labour Movement History), created in Austria in 1959. In 1960 the British Society for the Study of Labour History was founded. Since then, similar organizations have been formed in Ireland (1973) and Switzerland (1979). Southern Europe lagged behind, but in recent years has caught up. In 2010, Portuguese labor historians established a sizeable nationwide Research Group for Global Labor History and Social Conflicts (Grupo de Estudo História Global do Trabalho e dos Conflitos Sociais) with the support of the Instituto de História Contemporânea (IHC) of Lisbon's New University. ${ }^{4}$ On October 4, 2012, the Società italiana di storia del lavoro (Sislav) was founded in Rome. On June 15, 2013, the formation of a French association (Association française pour l'histoire des mondes du travail) followed. ${ }^{5}$ Shortly before the ELHN conference in Turin, a Greek Labor and Labor History Network was founded, and on December 16, 2015, during the conference, scholars of about twenty Spanish universities constituted a national network, the Red Española de Historia del Trabajo (REHT), inspired by the examples in adjacent Mediterranean countries and the arrival of the European Network. Meanwhile loose groups of labor historians also have come into existence in Iceland, Hungary, Malta, and Turkey.

Naturally, these trends stimulated cross-border collaboration as well. Since 1965 an annual International Conference of Historians of the Labor Movement (German acronym: ITH) is held in Linz, Austria. At first these gatherings were meant primarily as meeting places on neutral terrain for scholars from the East and West. The transformations in Eastern Europe landed the ITH in a crisis, which the organizers have resolved since the early 2000s by a turn toward global labor history. ${ }^{6}$ After the ITH other indications of a growing tendency toward supranational cooperation came quickly. In 1970 the International Association of Labour History Institutions (IALHI) was founded, an international meeting point for labor history archives and libraries. In 1997 LabNet was established-an electronic network for labor historians, which has been integrated into IALHI's so-called Social History Portal. ${ }^{7}$ Between 1977 and 1990 British and Dutch historians organized seven so-called Anglo-Dutch Labour History conferences, the conference sites alternating between the two countries. Between 1974 and 2005 Nordic labor history institutes jointly organized thirteen Labour History Conferences. ${ }^{8}$ After a ten-year interruption, the thread has been taken up again, partly stimulated by the creation of the ELHN. A further conference is now being scheduled for November 28-30, 2016, at the 
TAble One Some European Labor History Institutes, Associations, Networks, and Journals

\begin{tabular}{|c|c|c|c|c|}
\hline Name & Location & $\begin{array}{c}\text { Founding } \\
\text { year }\end{array}$ & Main activities & Website \\
\hline AMSAB-Institute of Social History & Ghent, Belgium & 1980 & $\begin{array}{l}\text { Archive; library; research; } \\
\text { Brood \& Rozen (1996- } \\
\text { present) }\end{array}$ & www.amsab.be \\
\hline Arbeiderbevegelsens Arkiv og Bibliotek & Oslo, Norway & 1908 & $\begin{array}{l}\text { Archive; library; } \\
\quad \text { Arbeiderhistorie (1987- } \\
\text { present) }\end{array}$ & www.arbark.no \\
\hline $\begin{array}{l}\text { Arbeidermuseet \& Arbejderbevaegelsens } \\
\text { Bibliotek og Arkiv }\end{array}$ & Copenhagen, Denmark & 1909 & $\begin{array}{l}\text { Archive; library; museum; } \\
\text { Arbejderhistorie (1995- } \\
\text { present) }\end{array}$ & db.humlenvedcarlsberg.dk \\
\hline Arbetarrörelsens Arkiv og Bibliotek & $\begin{array}{l}\text { Stockholm-Huddinge, } \\
\text { Sweden }\end{array}$ & 1902 & $\begin{array}{l}\text { Archive; library; research; } \\
\text { Arbetarhistoria (1985- } \\
\text { present) }\end{array}$ & www.arbark.se \\
\hline $\begin{array}{l}\text { Association française pour l'histoire des mondes } \\
\text { du travail }\end{array}$ & Paris, France & 2013 & Workshops, conferences & afhmt.hypotheses.org \\
\hline $\begin{array}{l}\text { Association pour l'étude de l'histoire du } \\
\text { mouvement ouvrier }\end{array}$ & Lausanne, Switzerland & 1979 & $\begin{array}{l}\text { Cahiers d'histoire du } \\
\text { mouvement ouvrier (1984- } \\
\text { present) }\end{array}$ & www.aehmo.org \\
\hline $\begin{array}{l}\text { Bibliothèque de documentation internationale } \\
\text { contemporaine (BDIC) }\end{array}$ & Nanterre, France & 1918 & $\begin{array}{l}\text { Archive; Library; Museum; } \\
\text { Matériaux pour l'histoire de } \\
\text { notre temps (1985-present) }\end{array}$ & www.bdic.fr \\
\hline 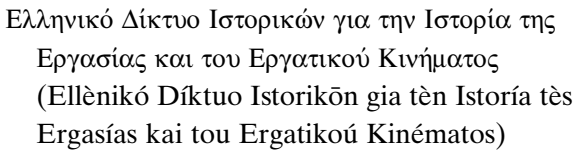 & Athens, Greece & 2015 & Developing & Under construction \\
\hline
\end{tabular}


Förderverein für Forschungen zur Geschichte der Arbeiterbewegung

Fondazione Giangiacomo Feltrinelli

\section{Työväen Arkisto}

Archiv der sozialen Demokratie, Friedrich Ebert Stiftung (FES)

Institut d'histoire sociale

Institut français d'histoire sociale

Institut für soziale Bewegungen

International Institute of Social History (IISH)

International Conference of Labour and Social Linz, Austria History (ITH)

Irish Labour History Society/Cumann Stair Saothair na hÉireann

István Hajnal Circle
Berlin, Germany

Milan, Italy

Helsinki, Finland

Bonn-Bad Godesberg, Germany

Paris, France

Paris, France

Bochum, Germany

Amsterdam, the Netherlands

Dublin, Ireland

Budapest, Hungary
1991

1909

1925

1935

1935

1965

1973

1989
Arbeit-BewegungGeschichte (2016-present)

Archive; library; Annali (1958-present)

Työväentutkimus (1987present)

Archive; library; research; Archiv für Sozialgeschichte (1961-present)

Cahiers d'histoire sociale (1993-)

Archives; Le Mouvement Social (1960-present)

Archive; library; Moving the Social (2013-present)

Archive; library; research; International Review of Social History (1956present)

Annual conferences; conference proceedings

Conferences; Saothar (1974present)

Annual conferences; research; Korall (2000present) www.foerderverein. arbeiterbewegung-jahrbuch. de

www.fondazionefeltrinelli.it

www.tyark.fi

www.fes.de

www.souvarine.fr

www.codhos.asso.fr/ifhs.htm

www.isb.ruhr-uni-bochum.de

www.socialhistory.org

\section{www.ith.or.at}

www.irishlabourhistorysociety. com

hajnalkor.hu/english

.




\begin{tabular}{|c|c|c|c|c|}
\hline Name & Location & $\begin{array}{c}\text { Founding } \\
\text { year }\end{array}$ & Main activities & Website \\
\hline Llafur: The Welsh People's History Society & $\begin{array}{l}\text { Swansea, United } \\
\text { Kingdom }\end{array}$ & 1970 & Llafur (1972-present) & www.llafur.org \\
\hline Red Española de Historia del Trabajo (REHT) & Barcelona, Spain & 2015 & Developing & www.um.es/reht \\
\hline Schweizerische Sozialarchiv & Zürich, Switzerland & 1906 & Archive; library; research & www.sozialarchiv.ch \\
\hline Scottish Labour History Society & $\begin{array}{l}\text { Glasgow, United } \\
\text { Kingdom }\end{array}$ & 1966 & $\begin{array}{l}\text { Scottish Labour History } \\
\quad \text { (1975-present) }\end{array}$ & $\begin{array}{l}\text { www.scottishlabourhistory.org. } \\
\text { uk }\end{array}$ \\
\hline Società italiana di storia del lavoro (Sislav) & Genua, Italy & 2012 & Workshops and conferences & www.storialavoro.it/english \\
\hline Society for the Study of Labour History & Huddersfield, Britain & 1960 & $\begin{array}{c}\text { Conferences; Labour History } \\
\text { Review (1990-present) }\end{array}$ & www.sslh.org \\
\hline $\begin{array}{c}\text { Verein für die Geschichte der } \\
\text { Arbeiterbewegung (VGA) }\end{array}$ & Vienna, Austria & 1959 & Archive; library & www.vga.at \\
\hline
\end{tabular}


University of Iceland, Reykjavik. ${ }^{9}$ A conference in Istanbul in 2011 entitled "Working in the Ottoman Empire and in Turkey: Ottoman and Turkish Labour History within a Global Perspective" gave historians from Turkey, Greece, Egypt, Iran, and the Netherlands the opportunity to discuss common projects. ${ }^{10}$ Another important development has been the founding in 2012 of the International Association of Strikes and Social Conflicts, a Portuguese initiative in which not only European, but also South American labor historians cooperate. $^{11}$

Considering these trends, it is hardly surprising that the urge was increasingly felt to integrate activities at a continental level. A discussion at a colloquium in Dijon (January 24-25, 2013), where the founding of the French labor history association was being prepared, was decisive. On the spot, the colloquium's participants requested that I, as the representative of IISH (Europe's largest labor history institute), should take the initiative to establish a European network. Consequently, on October 12 about thirty labor-history study groups, associations, journals, archives, and libraries - from Iceland to Turkey and from Portugal to Finland - met in Amsterdam. Unanimously, it was determined that a federative network should be created that-applying a broad concept of "labor" - could function as a gateway to share knowledge and (digital) material, assist in joint grant applications, and promote research collaboration. Two priorities were decided. Firstly, the ELHN should also become an umbrella organization for small working groups (temporary or for an unlimited period) with specific topics or tasks; for example, journals' editorial policies, free and unfree labor, feminist labor history, occupational health and safety, workers' consent to extreme-right movements, or remuneration. Every scholar attached to the ELHN was invited to create a working group as a possibility to meet interesting parties from other countries. Secondly, the ELHN should organize a broad conference on labor history, the purpose of which would be to bring as many interested scholars together as possible, both senior researchers and young students. These activities were to be provisionally coordinated by a committee.

At a later meeting of the coordinating committee Stefano Musso, the president of the Italian Sislav, declared that his association was willing to organize the first conference in Turin. That was a marvelous offer. Such a first conference, unconventionally structured on the basis of self-organized working groups, was a big organizational challenge. But the Italian colleagues did a splendid job, with some practical assistance of IISH and ITH. The conference opened with an apposite keynote by Geoff Eley (Ann Arbor, MI) who outlined labor history's great challenges for the coming years. Thereafter, the roughly two hundred participants from all over Europe (including Russia) joined one of the twenty working groups. During the evenings there were general events, such as a movie showing, book presentations, and further debates. The strong emphasis on the gender dimension in many discussions was remarkable, as was the significant presence of feminist and gender historians. During the plenary closing session representatives of the various working groups gave brief accounts of 
their activities. The strengths and weaknesses of the conference model were debated as well. The organizational structure could be improved by having more plenary discussions, but the first ELHN conference was generally seen as an altogether great success and will serve as a basis for further thematic and practical improvements. A second conference is already foreseen for late 2017 in Paris/Nanterre. ${ }^{12}$

All this perhaps signals the beginning of labor history's revival in Europe, after its high point of the 1970s and its decline thereafter. To make a real continent-wide network possible, ELHN intends to encourage the development of East-Central and South-East European networks and cooperations. A new kind of transnational historiography would then become possible that could also make significant contributions to the further development of global labor history.

\section{NOTES}

1. I am grateful to Görkem Akgöz, Cristina Borderías, Christian de Vito, Keith Laybourn, Lukas Neissl, Silke Neunsinger, Leda Papastefanaki, Stéfanie Preziosi, Tibor Valuch, Matthias van Rossum, Astrid Verburg, Xavier Vigna, Donald Weber, and Christian Wicke for their comments on the first draft. Any remaining mistakes are mine.

2. I have attempted an inventory until the turn of the century in "Main West European Labour History Periodicals, 1911-2000," in Class and Other Identities. Gender, Religion and Ethnicity in the Writing of European Labour History, ed. Lex Heerma van Voss and Marcel van der Linden (New York and Oxford, 2002), 162-65. Table 1 of this article provides an incomplete survey of the present situation. There are, of course, also scholarly journals of a more general nature that have paid serious attention to labor history, such as the Quaderni storici (Italy), Mnemon (Greece), or the Vierteljahrshefte für Wirtschafts- und Sozialgeschichte (Germany).

3. After mergers with other publications, this journal has become the Tijdschrift voor Sociale en Economische Geschiedenis (since 2004) and no longer focuses exclusively on labor history.

4. ihc.fcsh.unl.pt/pt/investigacao/grupos-de-investigacao/item/2282-trabalho-e-conflitualidade (accessed July 22, 2016).

5. For background information on the Italian association, see the interview (in English) with Luca Baldissara at www.storialavoro.it/english (accessed July 22, 2016). For the French association, see David Hamelin, "Pour une histoire du travail!," Cahiers d'histoire. Revue d'histoire critique 124 (2014): 147-58 (an interview with founding members Nicolas Hatzfeld, Michel Pigenet, and Xavier Vigna).

6. David Mayer (Vienna) is currently preparing a history of the ITH.

7. www.socialhistoryportal.org (accessed July 22, 2016).

8. The so-called Nordic region includes Iceland, Norway, Denmark, Sweden, Finland, and the autonomous regions of the Faroe Islands, Greenland, and the Åland Islands and is therefore more encompassing than Scandinavia (Denmark, Sweden, Norway). Scandinavians may understand each other's languages, but Icelanders and Fins don't. English is therefore the Nordic lingua franca.

9. See, for information on this 14th Nordic Social and Labour History Conference, www. nordiclabourhistory.org (accessed July 22, 2016).

10. See the conference report by M. Erdem Kabaday1 and Kate Elizabeth Creasey in International Labor and Working-Class History 82 (2012): 187-200.

11. IASSC (www.iassc-mshdijon.fr) publishes the online journal Workers of the World (https://workersoftheworldjournal.wordpress.com) and organizes biannual conferences: in 2013 in Dijon and in 2015 in Barcelona. A third conference is scheduled for 2017 in São Paulo. 
12. The ELHN website is under construction. ELHN decided to join the new federative Global Labor History Network (GLHN), for which the foundations were laid at a meeting in Barcelona on June 16, 2015. GLHN is still at an embryonic stage. Its steering committee consists of scholars from Argentina, Canada, Japan, the Netherlands, Portugal, and Senegal. Both ELHN and GLHN can be contacted through Astrid Verburg (ave@iisg.nl). 